\section{Corruption and appointment}

SIR - Angel Pestaña's letter (Nature 375 , $626 ; 1995)$ outlines the difficulties in procuring stable positions for those engaged in scientific research in Spain. Pestaña uses the Spanish Scientific Research Council (CSIC) as a model to explain the situation, but the CSIC can probably be considered as the élite of Spanish research and the real situation is therefore much worse. An additional problem that he mentions only briefly is "secular endogamy in the universities". The 'Ley de Reforma Universitaria' (LRU), approved by parliament in the 1980s, was supposed to end such endogamy, while decentralizing the Spanish universities, creating new stable positions and facilitating the movement of personnel within the different universities. The theory was excellent, but in practice the LRU has failed to reform the corrupt university establishment.

Appointment committees for a permanent university lectureship consist of two members of the university and three outsiders from different universities. Almost invariably there is an 'official' candidate for the position, who has normally been in the job on a contract basis for a number of years; the 'official' candidate is almost inevitably the one appointed, sometimes with complete disregard for the greater suitability and higher standards of other applicants. Furthermore, due to the bureaucratic nature of the process, applying and preparing for a single lectureship costs an enormous amount of money and time (nine months is not unusual), with almost no guarantee of a fair examination.

Human capital investment should certainly be a priority in science policy in Spain. But a serious modernization of the universities, with a new, less bureaucratic, more pragmatic, flexible and fair system for university and other scientific appointments is much needed.

\section{Vicente Rodilla}

Department of Medicine and Therapeutics, University of Aberdeen,

Aberdeen AB9 2ZD, UK

\section{Climate treaty and equity}

SIR - Your leading article "Conflicts of interest on the greenhouse" (Nature 374, $483 ; 1995)$ raises some critical questions on climate change, several of which, as you point out, were not asked at the recent Berlin conference. But it also contains a few inaccuracies and points in need of clarification; these, in part, explain why such questions remain unaddressed.
Your statement that "in due course, equity requires that the same rules should apply to all emitting countries" seems to conflict with the principle of "common but differentiated responsibilities" embodied in the climate treaty. It would in fact be inequitable to impose the same rules on all countries, given the developed world's historical role in greenhouse gas emission - although the developing world, with a larger prospective role, will eventually require specific obligations.

Second, you say that China and India are classified in Annex II of the treaty: Annex II includes developed and not developing countries. But for the latter to take on further commitments will require more financial and technical assistance from the former than we have seen so far.

Finally, your well-taken point that issues of "entitlement" and per capita emissions are on the horizon reminds us that the climate treaty must ultimately be placed within the context of "sustainable development". As a prime example, rapidly developing China may become the world's leading emitter by 2020 ; yet its per capita emissions today are one-ninth those of the United States. Herein lies the unavoidable challenge of equitably including now-poor countries in a global warming regime.

Nevertheless, your hope that another conference will tackle these issues may be fulfilled. The Berlin mandate requires that negotiations for a protocol be conducted "with urgency", and the climate treaty itself allows for additional meetings under "extraordinary circumstances". Coming events may very well provide such a context.

\section{Seth Dunn}

US Climate Action Network,

1350 New York Avenue, NW,

Washington, DC 20005, USA

\section{Job for the boy?}

SIR - Grant applications, seminars, congress proceedings and reports of any kind: scientists are flooded with hard-to-refuse requests from colleagues and peers for ready-by-tomorrow papers that would take months to be properly digested and delivered. It might be useful to know, therefore, what to do in such circumstances. So we would like to propose St Expeditus as the patron of anyone facing deadlines. Although Nature's readers certainly include people of every race, sex, age and creed, we hope that, in the name of the independence and universality of science, we will be forgiven if this saint belongs to the Christian faith.

Although nothing is known about his life and the circumstances of his martyrdom, St Expeditus is honoured on 19 April together with St Donatus Hermogenes and 22 fellow Christians who were killed in
Melitenes (Cappadocia, Turkey) 1 . He is usually represented as a standing Roman soldier who crushes under his left foot a raven croaking the Latin word cras (tomorrow): this bird, indeed, was regarded by the ancients as the emblem of endless procrastination $^{2}$. St Expeditus holds the crown of martyrdom in one hand and indicates a clock with the other; in later images the clock is replaced by a cross bearing the Latin word hodie (today), meaning that one should never put off until tomorrow what can and must be done today.

Veneration for St Expeditus dates back at least to 1554, as demonstrated by a manuscript listing a church dedicated to him in the bishopric of Périgueux (Périgord, France $)^{3}$. In southern Germany the saint is still honoured and is represented in a wealth of engravings and paintings, the oldest of which, dated 1759 , bears the caption Patron deren so ihre geschaft glicklich vollenden wolen desen Fest so den 19 April (Patron of those who wish to bring their business to a happy end; his day is 19 April), while another reads Heute, noch, nicht mogen erst, Sei gethan, was Gott begehrt (What the Lord commands has to be done today, right now, not tomorrow) ${ }^{4}$. Since the mid-eighteenth century, the cult of St Expeditus has also been recorded in Sicily, especially in the maritime cities on the eastern coast of the island, such as Messina and Acireale, where the saint was proclaimed secondary patron and invoked by merchants and seamen for quick and safe clearing of their business (negotiorum et expeditionum patronus). Under a different, but corresponding name (St Minas, derived from the roots of expedite [speedy] and arakahas [fast-arriving]), this saint may also be identified in the Armenian Martyrology 5 .

Although such a veneration smells of superstition and originates probably from an easy pun on the saint's name, in popular belief St Expeditus has become the enemy of any postponement, and the person to whom to pray to obtain an immediate grace. The saint seems to have enjoyed a successful career, and can be rightly elected as patron of all desperate scientists asking for out-of-this-world help in meeting deadlines.

Mario G. Fiori

ExPharma s.r.l.,

Riviera Francia 3IA,

I-35127 Padova, Italy

Pier Giorgio Righetti

Interdisciplinary Laboratory

of Advanced Technologies,

University of Milano,

1-20090 Segrate (MI), Italy

1. Sauget, J.-M. in Bibliotheca Sanctorum 5, col. 95 (Istituto Giovanni XXIII della Pontificia Università Lateranense, Città Nuova Editrice, Roma, 1964).

2. Cahier, P. C. Caractéristiques des Saints dans l'Art populaire 1, 256 (Poussielgue, Paris, 1867).

3. Lavialle, J. Semaine réligieuse, Périgueux, 16 décembre 1905.

4. Kaul, L. La Civiltà Cattolica 56, 718-727 (1905).

5. Aucher, G. La Civiltà Cattolica 57, 448-460 (1906). 